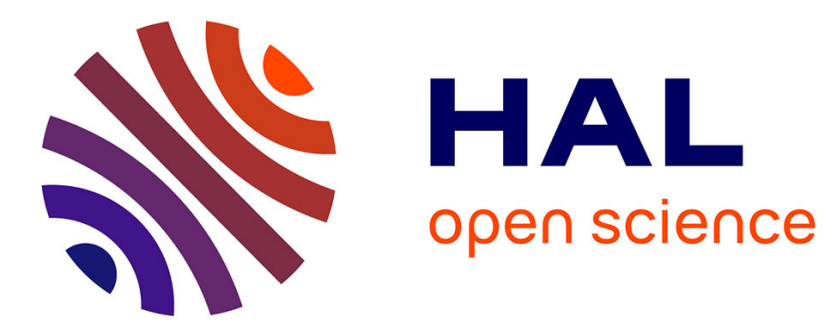

\title{
Positioning and orientation of adherent cells in a microfluidic chip using the micro patterning of a parylen-C-film
}

Claire Dalmay, Yung-Yung Lai, Laurent Griscom, Olivier Français, Bruno Le Pioufle, Frédéric Subra, Patrick Tauc, Joseph Lautru

\section{To cite this version:}

Claire Dalmay, Yung-Yung Lai, Laurent Griscom, Olivier Français, Bruno Le Pioufle, et al.. Positioning and orientation of adherent cells in a microfluidic chip using the micro patterning of a parylen-C-film. biodevices, 2011, Rome, Italy. hal-00739185

\section{HAL Id: hal-00739185 \\ https://hal.science/hal-00739185}

Submitted on 19 Feb 2013

HAL is a multi-disciplinary open access archive for the deposit and dissemination of scientific research documents, whether they are published or not. The documents may come from teaching and research institutions in France or abroad, or from public or private research centers.
L'archive ouverte pluridisciplinaire HAL, est destinée au dépôt et à la diffusion de documents scientifiques de niveau recherche, publiés ou non, émanant des établissements d'enseignement et de recherche français ou étrangers, des laboratoires publics ou privés. 


\title{
POSITIONING AND ORIENTATION OF ADHERENT CELLS IN A MICROFLUIDIC CHIP USING THE MICRO PATTERNING OF A PARYLENE-C FILM
}

\author{
Claire Dalmay, Yung-Yung Lai, Laurent Griscom, Olivier Français, Bruno Le Pioufle \\ CNRS SATIE, IFR d'Alembert, ENS Cachan, Cachan, France \\ claire.dalmay@satie.ens-cachan.fr,_Laurent.Griscom@bretagne.ens-cachan.fr,olivier.francais@satie.ens-cachan.fr. \\ bruno.lepioufle@satie.ens-cachan.fr \\ Frédéric Subra, Patrick Tauc \\ CNRS LBPA, IFR d'Alembert, ENS Cachan, Cachan, France \\ fsubra@lbpa.ens-cachan.fr,patrick.tauc@ens-cachan.fr \\ Joseph Lautru \\ IFR d'Alembert, ENS Cachan, Cachan, France \\ joseph.lautru@ens-cachan.fr
}

Keywords: Parylene-C, living cells, micro patterning, cell positioning, biodevice.

\begin{abstract}
A new biochip for adherent cell trapping using micro patterned parylene-C is presented. We demonstrate the ability of micro patterned parylene-C films to provide an efficient positioning and orientation of cells. It is also possible to fix one cell separate from the others which may be crucial in the development of biodevices for the single-cell analysis. The developed method does not require any chemical treatment of either cells or surface attachment and is suitable to be integrated into a microfluidic system.
\end{abstract}

\section{INTRODUCTION}

This paper reports a novel method, based on parylene-C patterning, for on chip cell positioning. This new developed approach finds various applications like the orientation of cells on biodevives as well as the study of cell motility for example. We demonstrate the ability of microstructured parylene-C for the functionalization of biochip surfaces. In this way, cells are grown directly on-chip. Current approaches use parylene-C stencils to reach spot of cells. In this configuration, the parylene-C film is peeled-off after the cell culture. Finally, cells have grown on the substrate depending on the parylene-C film shape [1, 2]. Such approaches are also used to pattern proteins, on glass substrates, into various shapes with a high resolution [3].

This approach is not compatible with the integration in a functional microfluidic chip as (i) the peeling of the parylene film inside a fluidic chamber or channel is not permitted (ii) the adherent cells progressively spread out from the initial patterns once the parylene stencil is removed.

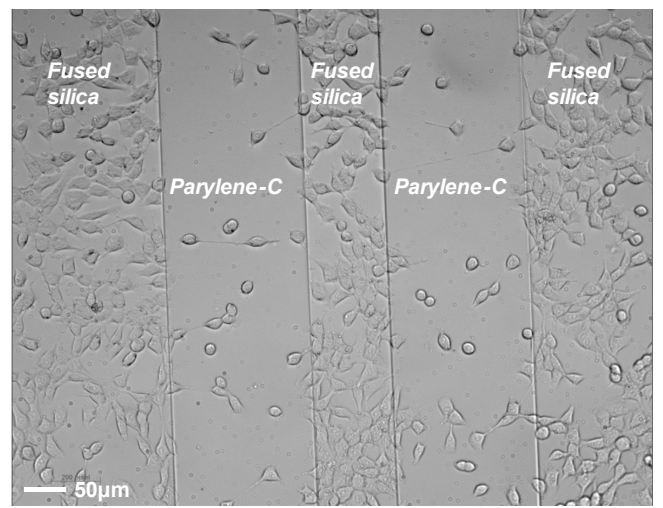

Figure 1: Photograph of NIH-3T3 EWS/fli fibroblasts cultured on a substrate of fused silica covered with two lines of parylene-C.

We show in this paper that the difference in term of surface properties of parylene-C versus fused 
silica, combined to the use of specific nanosized or microsized patterns is capable to induce a precise cell patterning, or even the orientation of cells towards specified directions. Our protocole does not require the removal of the parylene- $\mathrm{C}$ film after the cell culture.

In fact, the method takes benefit of parylene properties like biocompatility, biostability, chemical inertia and hydrophobic nature. Previous works have demonstrated that the nature of the substrate, as rigidity for example, influence the cell movement [4]. The difference of cell affinity between parylene$\mathrm{C}$ and a fused-silica substrate makes cells adhere preferentially on the fused silica substrate (Figure 1).

Combined with the patterning of different shape based on lines or plots in the parylene film (Figure 2 ), we obtain also a preferential orientation of cells on the substrate.

The paper highlights that the cells are repulsed from small patterns in parylene either in case of dots or micro-holes as soon as the size of the patterns is an order of magnitude lower than the cell size.

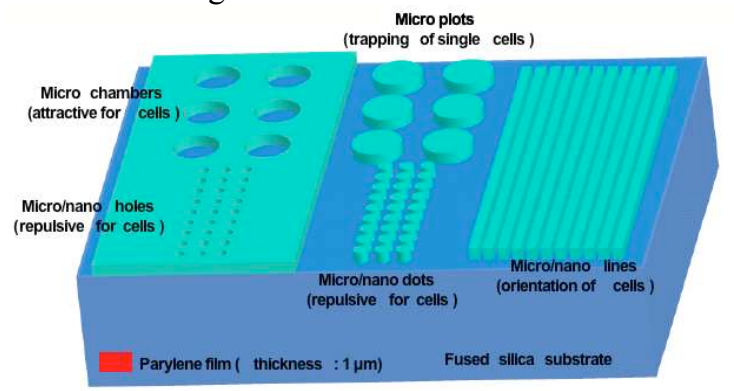

Figure 2: Schematic of the patterned parylene film onto the fused silica substrate (arbitrary scale).

\section{EXPERIMENTAL SETUP}

\subsection{Fabrication process}

The chip is fabricated using a standard microelectronic process. First, a $1 \mu \mathrm{m}$ thick film of parylene-C is deposited on a 2 inches fused silica substrate; the deposition is made by Chemical Vapour Deposition after silanization to ensure a good adhesion of the film. Then, the parylene-C is patterned by plasma oxygen through an aluminium mask (Figure 3). At the end of the etching, the aluminium is removed using a chemical solution based on Sodium Hydroxide. To finish, the biochip is sterilized under UV light to ensure that no contamination appears during the cell culture.

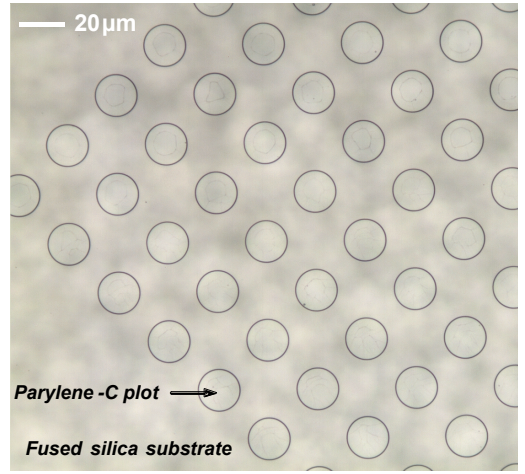

Figure 3: Photograph of a $1 \mu \mathrm{m}$ thick parylene-C film after the patterning.

\subsection{Material and methods}

Biological tests have been performed using NIH3T3 EWS/fli fibroblasts which present a high motility (Figure 4). These cells have been especially chosen for their good properties of adherence and migration.

First cells are grown in Minimum Essential Medium supplemented with $10 \%$ foetal bovine serum and $10 \%$ streptomycin at $37^{\circ} \mathrm{C}$ in a humidified 5\% CO2 - 95\% air incubator.

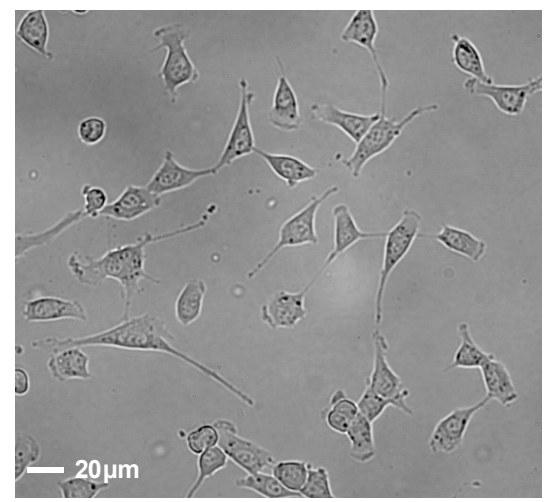

Figure 4: Photograph of a NIH-3T3 EWS/fli fibroblasts culture.

Then, cells are collected and counted to put an appropriate concentration of cells on the chip. The 2 inches chip is put into a Petri dish and submerged in the culture media. Then, about 200000 cells are added into the media. After few hours cells have adhered to the chip. We make the observation of cells during several days to monitor them and see the effect of the micro patterning on their behaviour. 


\section{BIOLOGICAL RESULTS}

Biological experimentations led on these types of structures pointed out several interesting phenomenon especially for their integration in biodevices to make cell positioning or to orient cells in a specific way.

First, we have shown that as cells adhere preferentially onto the fused silica substrate rather than onto the parylene- $C$, it is possible to trap cells in specific areas of the biochip as shown on Figure 5. (Figure 5 has to be compared to Figure 4 (control experiment).

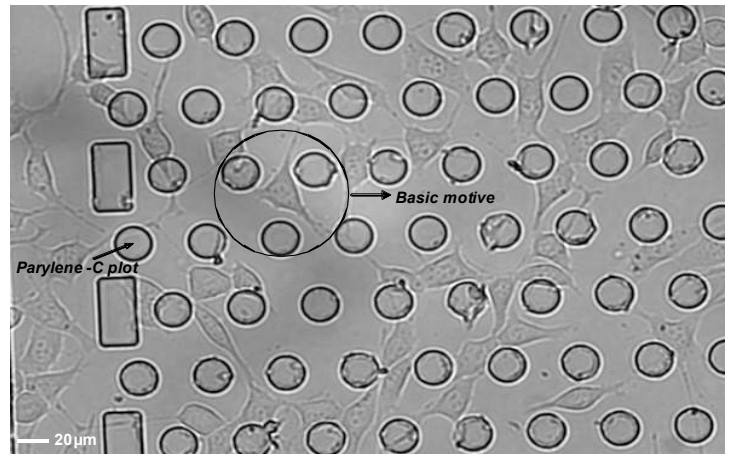

Figure 5: $20 \mu \mathrm{m} \times 20 \mu \mathrm{m}$ network of parylene plots: photograph of cells after 82 hours in culture.

Notice that plots separated by a cell diameter distance are very interesting especially to develop single-cell analysis chips as they may permit to isolate only one cell between plots (Figure 5).

In addition, we have also demonstrated that cells are strongly repealed from the areas patterned with parylene dots (figure 6.a.). In the same way, microholes in the parylene may enhance the repulsion of cells (Figure 6.b). These assumptions are verified as soon as patterns characteristic sizes are under $5 \mu \mathrm{m}$.

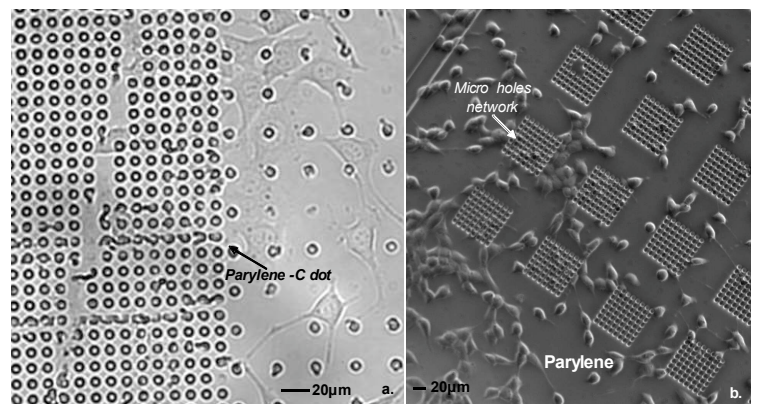

Figure 6: a. $5 \mu \mathrm{m} \times 10 \mu \mathrm{m}$ network of parylene micro holes and b. $5 \mu \mathrm{m} \times 5 \mu \mathrm{m}$ network of parylene dots: photograph of cells after 82 hours in culture.
And finally, we have developed a micro patterning which allows for the orientation of cells. Indeed, an array of thin lines (typical width between 1 to $3 \mu \mathrm{m}$ ) of parylene-C allows the adherent cells orientation. As shown on Figure 7, cells are able to grown along the same direction as the one of lines. It is to compare as a classical cell culture (Figure 4) for which cell prolongations may be in all directions. This phenomenon which consist in making cells grown in preferential direction can be very interesting for the study of many biological mechanisms.

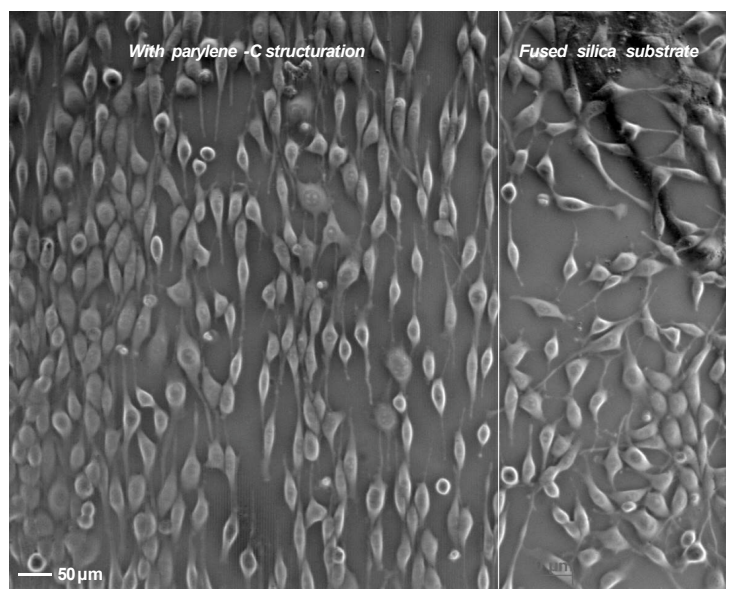

Figure 7: Figure 3. $2 \mu \mathrm{m} \times 2 \mu \mathrm{m}$ network of parylene lines: photograph of cells after 38 hours in culture.

\section{CONCLUSIONS}

These results demonstrate the high capability of micro patterned parylene film on fused silica substrate to position and orientate adherent cells. The developed technique is fully adapted to the use inside a microfluidic system making it very attractive in the biodevice field. In addition, the possibility to isolate cells may be very promising in the development of biodevices for single-cell analysis.

\section{REFERENCES}

Wright, D., Rajalingam, B., Selvarasah, S., Dokmecid, M.R., Khademhosseini, A., 2007. Generation of static and dynamic patterned co-cultures using microfabricated parylene-C stencils. Lab Chip, 7, 1272.

Tan, C.P., Ri Seo, B., Brooks, D.J., Chandler, E.M., Craigheadb, H.G., Fischbach, C., 2009. Parylene peel- 
off arrays to probe the role of cell-cell interactions in tumour angiogenesis. Integr. Biol., 1, 587.

Atsuta, K., Suzuki, H., Takeuchi, S., 2007. A parylene liftoff process with microfluidic channels for selective protein patterning. J. Micromech. Microeng., 17, 496.

Lo, C.M., Wang, H.B., Dembo, M., Wang, Y.L., 2000.

Cell movement is guided by the rigidity of the substrate. Biophysical Journal, 79, 144. 